ROCZNIKI PEDAGOGICZNE

Tom 13(49), numer $2-2021$

DOI: https://doi.org/10.18290/rped21132.6

ANNA BADORA

\title{
TWÓRCZOŚĆ JAKO ZADANIE OSOBY
}

\section{TWÓRCZOŚĆ JAKO ZADANIE OSOBY W ŚWIETLE LITERATURY}

Twórczość stanowi zagadnienie bardzo rozległe i wielowymiarowe. Rozumienie tego pojęcia odnosi się do wielu poziomów i perspektyw. Należy jednak podkreślić, iż „punktem” połączenia i przenikania się każdej z tych perspektyw jest osoba. Twórczość bez osoby nie zaistnieje. Jak piszą K. Chałas i M. Łobacz,

\begin{abstract}
Rozpatrując zdolność do twórczości jako przymiot osoby należy podkreślić, że wśród istot żywych tylko człowiek jest zdolny do aktywności twórczej, w niej ma wyrażać i potwierdzać, ubogacać nią drugiego człowieka, grupy, wspólnoty, społeczeństwo poprzez swoją twórczość wchodzić w relacje z innymi i tworzyć twórcze mikrośrodowisko. Twórczość ma uniwersalny charakter, towarzyszy człowiekowi od zarania dziejów, aż po współczesność i trzeba mieć nadzieję, że będzie towarzyszyć zawsze; dotyczy każdej dziedziny życia; stanowi czynnik budowania kultury i rozwoju człowieka (Chałas, Łobacz, 2020, s. 109).
\end{abstract}

Twórczość jest wpisana w działalność człowieka, dynamizuje jego rozwój, jednak nie może zostać urzeczywistniona samoistnie, potrzebuje wielowymiarowego podmiotu, który będzie w sposobności do jej wypełnienia. Według G. Mendeckiej

Nie można analizować rozwoju człowieka, jeśli nie przyjmie się, że ma on charakter twórczy. Poza tym trudno jest zdefiniować twórczość ludzką bez uwzględnienia faktu, że wpływa ona zarówno na indywidualny poziom rozwoju, jak i determinuje go. Ta zależność wydaje się oczywista, jeśli kreatywność postrzega się jako cechę egalitarną. Zdolność tworzenia nie jest dychotomią, tj. obecną lub

Dr ANNA BADORA - Katedra Dydaktyki, Edukacji Szkolnej i Pedeutologii, Instytut Pedagogiki, Wydział Nauk Społecznych, Katolicki Uniwersytet Lubelski Jana Pawła II; adres do korespondencji: Al. Racławickie 14, 20-950 Lublin; e-mail: anna.badora@kul.pl; ORCID: https://orcid. org/0000-0003-4027-6792. 
nieobecną, ale stanowi ciągłą cechę, powszechnie obecną w rodzaju ludzkim (Mendecka, 2005, s. 26).

W tym kontekście należy wskazywać na istnienie swoistej relacji między twórczością i osobą. W tym związku osoba doskonali siebie przez twórczość i przekształca uwarunkowania zewnętrzne pośrednio i bezpośrednio z nią powiązane, twórczość z kolei zyskuje prawo do zaistnienia i trwania. Jednak ostatecznym celem działań twórczych jest osoba i wspomaganie jej integralnego rozwoju. Jak pisze K. Najder-Stefaniak,

Twórczość to działalność teoretyczna i praktyczna, której celem jest twórczy człowiek z jego zdolnościami i umiejętnościami, umożliwiającymi twórcze życie; aktywność wyrażająca się w sprawności przekształcania i wytwarzania czegoś nowego oraz oryginalnego; ściśle związana z poznaniem, inteligencją, motywacją, cechami osobowości oraz środowiskiem społeczno-kulturowym i wychowawczym (Najder-Stefaniak, 2016, s. 1183).

Ukierunkowanie na rozwój osoby warunkuje postrzeganie działalności twórczej w kategorii zadania, które zostało wyznaczone dla każdego człowieka. W tym kontekście warto wskazać na dwojaką specyfikę twórczości. B. Kaczmarska podkreśla:

\footnotetext{
Powszechnie wiadomo, że każdy człowiek potrafi tworzyć, twórczość bowiem jest potencjałem tkwiącym w ludzkim umyśle. Trzymając się takiego wniosku, można by stwierdzić, że twórczość jest umiejętnością uniwersalną, przynależną z zasady każdemu człowiekowi. Jednakże po dogłębnej analizie i zastanowieniu można dojść do wniosku, że twórczość to jednak zjawisko wyjątkowe, ponieważ do tego, by móc tworzyć, niezbędny jest nie tylko sam talent, ale przede wszystkim cel, motywacja, chęć działania i czerpanie przyjemności z tego, co się tworzy (Kaczmarska, 2017, s. 108).
}

Zarówno powszechność, jak i wyjątkowość twórczości mają swoje źródło w akcie stworzenia osoby. Według M. Szymańskiej i S. Szymańskiego „Antropologiczno-aksjologiczne podejście do twórczości będzie traktować ją w kategoriach antyczno-ontologicznych. W chrześcijańskiej perspektywie personalistycznej należy przyjąć, że człowiek stworzony na obraz i podobieństwo Boga jest obdarzony właściwością twórczości, gdyż Bóg jest Creatorem, czyli Stwórcą" (Szymańska, Szymański, 2017, s. 226).

Stwarzając człowieka, Bóg wyposaża go w narzędzie służące do przekształcania rzeczywistości oraz daje wyraz podobieństwa osoby do Niego samego. Innymi słowy, każda osoba dysponuje darem aktywności twórczej 
i w tej aktywności staje się niepowtarzalna i wyjątkowa, ta działalność stanowi kontynuację aktu Stwórcy.

Potencjał twórczy konkretnej osoby jest przestrzenią zadaną, którą nieustannie potrzeba doskonalić. Dlatego mimo swojej powszechności, twórczość będzie się charakteryzowała wielopoziomowością i zróżnicowaniem jakościowym. Jak pisze E. Nęcka,

Twórczość jako dorobek i jako rodzaj aktywności to bynajmniej nie wszystkie znaczenia interesującego nas pojęcia. Mówimy na przykład, że ktoś cechuje się twórczością, bo dużo i mądrze pisze albo ma ciekawe pomysły. W tym wypadku „twórczość” oznacza cechę indywidualną, swego rodzaju wyposażenie intelektualne konkretnej osoby. Mało tego, możemy o kimś powiedzieć, iż jest osobą twórczą, mimo iż niczego nie napisał ani nie odkrył. Chodzi nam wtedy o cechę latentną, ukrytą, świadczącą o możliwościach tej osoby, a nie o jej rzeczywistych osiągnięciach (Nęcka, 2016, s. 12).

Podobnie uważa K. J. Szmidt:

Twórczość rozumiana szeroko i egalitarnie jako aktywność lub postawa całożyciowa, którą wykazują się na różnych poziomach niemal wszyscy ludzie, może stanowić w pedagogice pozytywną ideę przewodnią, oś, wokół której rozwijać się mogą inne idee i badania. Przemawiają za tym różne względy teoretyczne i praktyczne (Szmidt, 2013, s. 16).

To osoba staje się głównym decydentem w procesie realizacji aktywności twórczej. Specyfika twórczości jest indywidualnie powiązana z samym twórcą - wynika z wyjątkowości konkretnej osoby, ale jednocześnie staje się czynnikiem kształtującym i zmieniającym twórcę. Według A. Nalaskowskiego

Twórczość będzie działaniem, którego celem jest zmiana stanu konieczności na stan wyboru. Koniecznością może być też wiele wariantów danego przedmiotu (w sensie logicznym przedmiotu istnienia), które jednostka zastaje. Na skutek pewnych operacji dochodzi do podjęcia aktywności, która zmierza do zmiany konieczności przyjęcia jednego z istniejących wariantów na możliwość wybierania wariantu jeszcze nie obecnego (Nalaskowski, 1998, s. 15).

Warto w tym kontekście zaznaczyć, iż działalność twórcza nie tylko umożliwia poszukiwanie nowych wariantów danego przedmiotu, jej podlegającemu, lecz także stwarza przestrzeń do poszukiwania i odkrywania nowych elementów własnego ja osoby.

Należy stwierdzić, iż twórczość, mająca szczególną dynamikę oddziaływania na osobę twórcy, nie zamyka się w wymiarze wyłącznie indywidualnym. 
Przeciwnie, jednocześnie wypełnia i przekształca wymiar społeczny rzeczywistości. Jak zaznacza J. Kozielecki,

\begin{abstract}
Człowiek potwierdza lub wzmacnia poczucie własnej wartości dzięki stałemu polepszaniu swoich osiągnięć, dzięki podnoszeniu standardów perfekcji, dzięki sięganiu po mistrzostwo. [...] Podejmując czyny ekspansywne i twórcze, przekraczając granice własnych osiągnięć, ludzie niestrudzenie dążą do potwierdzenia wartości własnej osoby, do zwiększenia swojej ważności wśród innych. Chodzi im zatem o osiągnięcie osobistych celów. Mimo iż motywacja ta jest egoistyczna, może prowadzić do czynów prospołecznych i często rzeczywiście do nich prowadzi (Kozielecki, 1996, s. 54).
\end{abstract}

Rodzaj motywacji, przez którą podejmowana jest działalność twórcza, nie determinuje jej zamknięcia na kontekst społeczny. Przeciwnie, bez względu na poziom egoistycznych pobudek twórczość osoby będzie przyczyniała się do realizacji dobra dla drugiego człowieka.

Jak podkreśla Szmidt, „Pedagogika twórczości interesuje się wszystkimi czterema wymiarami twórczości, które - jak powszechnie się sądzi - dobrze opisują złożoność tego zjawiska: osobę twórcy procesem tworzenia, wytworem twórczości oraz uwarunkowaniami zewnętrznymi, które stymulują lub hamują aktywność twórczą człowieka" (Szmidt, 2009, s. 14). Złożoność zjawiska twórczości stanowi swoiste potwierdzenie dla jej integralności z osobą. Tak wielowymiarowe narzędzie, jakim jest twórczość, jest dostępne jedynie dla bytu podobnie wielowymiarowego - czyli dla osoby.

Podsumowując powyższe analizy należy podkreślić, iż twórczość - jako zadanie osoby - jest determinowana przez następujące właściwości:

- twórczość i osoba pozostają we wzajemnej relacji trwania;

- twórczość przynależy każdemu człowiekowi i jednocześnie wyznacza jego wyjątkowość;

- w twórczości osoba odkrywa swoje ja;

- wielowymiarowość twórczości jest integralnie powiązana $\mathrm{z}$ wielowymiarowością osoby.

W dalszej części artykułu przedstawiono analizę swobodnych wypowiedzi nauczycieli na temat twórczości.

\title{
2. TWÓRCZOŚĆ JAKO ZADANIE OSOBY W OCENIE BADANYCH NAUCZYCIELI
}

Dwudziestu jeden nauczycieli poproszono o sformułowanie wypowiedzi odnośnie do stwierdzenia „Twórczość jako zadanie osoby”. Wśród responden- 
tów było siedmiu nauczycieli przedszkoli, pięciu edukacji wczesnoszkolnej, czterech z klas starszych szkoły podstawowej oraz pięciu uczących w szkołach ponadpodstawowych. Analiza przesłanych wypowiedzi umożliwiła wskazanie trzech aspektów, które stanowią odpowiedź na postawiony problem badawczy:

1) Twórczość jest powołaniem osoby;

2) Twórczość jest czynnikiem kształtującym osobę;

3) Twórczość jest powinnością osoby wobec innych;

4) Twórczość jest zadaniem nauczyciela.

\section{1) Twórczość - powołaniem osoby}

Pierwszym aspektem, na który wskazywali badani nauczyciele, jest twórczość jako powołanie osoby. Jak podkreślali, twórczość jest wpisana w funkcjonowanie każdego człowieka. Jest przynależna każdej osobie, stanowi dla niej dar.

Jeden z nauczycieli zaznacza: „Wykonując nawet najprostsze czynności, możemy je robić twórczo. Twórczość to nasze talenty i je należy rozwijać i dzielić się nimi. Twórczość jest naszą indywidualnością i nas wyróżnia”. Inny nauczyciel podkreślił, że: „Każda osoba wyraża się poprzez swoją twórczość niezależnie od tego, czy jest to sposób nauczania, malarstwo, rzeźba, czy chociażby sposób ustawienia sztućców w szufladzie”.

Twórczość stanowi swoiste potwierdzenie dla niepowtarzalności każdej osoby. Przez podejmowanie działań twórczych osoba realizuje indywidualny, tylko jej przypisany plan życia. Dodatkowo możliwość tworzenia przynależy tylko człowiekowi, który jako osoba został stworzony na obraz i podobieństwo swego Stwórcy. Akt tworzenia ma swoje źródło w akcie stworzenia. Jak podkreśla kolejny nauczyciel, „Twórczość jako zadanie osoby to powinność każdego człowieka do budowania, tworzenia czegoś nowego, czego wcześniej nie znano. Kryterium nowości jest potwierdzające dla zaistnienia twórczości”. „Nowość” zaświadczająca o twórczości może mieć charakter subiektywny i obiektywny. Nowość subiektywna jest związana z indywidualnymi doświadczeniami osoby, nowość obiektywna wiąże się z dotychczasowym dorobkiem cywilizacyjnym. Dwojaki charakter nowości wyznacza główne funkcje twórczości: poszerzanie zasobu doświadczeń osoby oraz poszerzanie zasobu doświadczeń cywilizacyjnych.

Nauczyciele wskazywali, że twórczość - jako działalność - nie jest czymś niezwykłym, realizującym się tylko w wyjątkowych sytuacjach. Jeden z nich zaznacza: „Każdy człowiek w swej aktywności podejmuje różne dzia- 
łania. Każde działanie podejmowane na nowo jest, pomimo swojego podobnego schematu, zupełnie nowym zadaniem. Dzięki podejmowaniu działań każdy człowiek wykonuje określone wytwory, czy to w postaci rzeczy, czy też w postaci myśli, pewnych koncepcji. Te wytwory, kiedy się nad tym mocniej zastanowić, układają się $\mathrm{w}$ pewien system działań, które człowiek podejmuje niejako z automatu, każdego dnia. Staje się to jego codziennym zadaniem”. Podobnie ocenia inny nauczyciel, pisząc „Twórczość jest naszą codziennością".

Twórczość „towarzyszy” osobie każdego dnia. Kolejne wyzwania i trudności wymagają od człowieka poszukiwania efektywnych rozwiązań. Twórczość staje się również przestrzenią dla zmiany tego, co już poznane i oswojone. W tym kontekście należy ją postrzegać jako narzędzie umożliwiające kształtowanie rzeczywistości wewnętrznej i zewnętrznej człowieka.

Jeden $\mathrm{z}$ nauczycieli $\mathrm{w}$ taki sposób formułuje swoją wypowiedź: „Twórczość jako zadanie osoby jest ukierunkowaniem każdego z Nas na całokształt jego dorobku, jak i na poszczególne dzieła wytworzone przez niego na różnych etapach życia. Twórczość jest również procesem samym w sobie, postrzegam ją jako powstawanie czegoś nowego, wartościowego, co przyczynia się do rozwoju osoby tworzącej - twórcy oraz innych współtowarzyszących temu procesowi osób. W tych dwóch aspektach jest to zadanie dla osoby na całe życie. Odnosi się do uczenia się nowych rzeczy, doskonalenia poznanych już umiejętności, poszukiwania nowych rozwiązań, samorealizacji poprzez proces twórczy, eksponowania własnych osiągnięć, inspirowania innych, nadawania nowego znaczenia rzeczywistości poprzez dzieło, konfrontowania własnych pomysłów z innymi”.

Badany podkreśla w swojej wypowiedzi, że twórczość jest aspektem wpisanym w człowieczeństwo, niezależnie od wieku. Twórczość została przypisana osobie na całe jej życie, w pewien sposób „domaga” się realizacji. Chociażby twórczość wybitna, która odpowiada za postęp cywilizacyjny, determinuje konieczność podejmowania twórczości codziennej. Zmiany zachodzące w otaczającym świecie, zarówno w przestrzeni publicznej, jak osobistej - rodzinnej, wymagają działań twórczych. Twórczość stanowi w tym kontekście narzędzie przystosowawcze do dokonujących się przemian.

Podsumowując powyższe analizy należy zaznaczyć, iż twórczość jest nie tylko zadaniem osoby, lecz także jej powołaniem. Wypełnianie tego zadania ma na celu:

- urzeczywistnianie indywidualnego planu życiowego osoby;

- rozwój człowieka oraz całej cywilizacji; 
- towarzyszenie w codzienności osoby;

- pomoc w całożyciowym przystosowywaniu się do zmian.

Realizacja powołania osoby, jakim jest twórczość, determinuje potencjał kształceniowy twórczości - jest to kolejny element, na który wskazywali respondenci.

\section{2) Twórczość czynnikiem ksztaltującym osobę}

Kolejnym aspektem, na który wskazywali badani w swoich wypowiedziach, było określenie twórczości jako czynnika kształtującego osobę. Nauczyciele podkreślali, iż w twórczości nie jest istotny sam efekt twórczości, ale także sposób kształtowania wytworu. Szczególnie jest to ważne w twórczości dziecięcej, która w aspekcie wytworów nie przynosi spektakularnych efektów, ale przez urzeczywistnienie procesu tworzenia jest czynnikiem prorozwojowym. Jeden z nauczycieli zaznacza „Twórczość to oryginalność, kreatywność, działanie dające wiele satysfakcji i radości. U dzieci to spontaniczne odkrywanie świata, a co za tym idzie, nieustanny ich rozwój w różnych dziedzinach".

Nauczyciele wskazywali na dwuwymiarowość w zakresie potencjału dynamizacji rozwoju, którym dysponuje twórczość. Wprowadzenie do procesu wychowawczo-dydaktycznego przestrzeni dla twórczości uczniów pozwala tak zorganizować treści kształcenia, aby mogli oni aktywnie odkrywać wiedzę, zdobywać umiejętności, przyjmować postawy, nie zaś biernie przyswajać informacje dla każdego z tych zakresów. W tym kontekście twórczość usprawnia poznawanie rzeczywistości, co stanowi fundament dla podjęcia działań, które tę poznaną rzeczywistość będą przekształcać. Umożliwiają one rozpoznanie potrzeb ulepszenia, a także wykrycie braków koniecznych do uzupełnienia. Ta specyfika twórczości człowieka odróżnia ją od aktu stworzenia Boga. Osoba tworzy z materii istniejącej, Bóg stwarza z braku.

Drugi wymiar $w$ zakresie potencjału dynamizacji rozwoju twórczości odnosi się do samej osoby. Jak stwierdza jeden z nauczycieli: „Twórczość drzemie w każdym z nas, trzeba ją tylko odkryć i odpowiednio stymulować. Każdy nauczyciel ma za zadanie być twórczym. Twórczość polega na tworzeniu czegoś nowego, wartościowego. Osoby twórcze są odważne, silne, dociekliwe oraz otwarte na owe nowości. Mają ogromną siłę woli oraz upór”. Podobną myśl wyraził inny badany: „Twórcze życie czyni je bowiem bardziej interesującym, odważnym; potrafi być inspiracją do życia, które nie zamyka się w szablonach, lecz jest otwarte na to, co nowe, niespodziewane, zaskakujące i piękne". 
Nauczyciele w swoich wypowiedziach wskazywali, że podejmowanie działalności twórczej w bardzo konkretny sposób kształtuje samego człowieka. Realizacja twórczości przygotowuje osobę do spotkania ze zmianą. Trudność i nieznane przestają być przestrzenią lęku, a stają się wyzwaniem, które jest kolejnym etapem na drodze rozwoju. Przyjmując postawę twórcy, osoba przeciwstawia się marazmowi i stagnacji, rzeczywistość rozpatruje w kategorii przestrzeni do działania. Człowiek twórczy wymaga od siebie nieustannego wysiłku w celu doskonalenia siebie oraz zastanego świata. Co więcej, osoba twórcza nie przyjmuje postawy oczekiwania na zadania do realizacji, przeciwnie - sama ich poszukuje, analizując swoją przestrzeń wewnętrzną oraz zewnętrzną.

Podsumowując powyższe analizy należy podkreślić, iż twórczość jest zadaniem osoby, ponieważ stanowi dla niej samej czynnik kształtujący. W tym zakresie twórczość umożliwia osobie: efektywne, dogłębne poznawanie rzeczywistości; przekształcanie rzeczywistości; rozwój postawy twórczej, w której zawiera się odwaga do realizowania zmian, oraz samodzielne poszukiwanie przestrzeni do realizacji działań twórczych.

Badani w swoich wypowiedziach wskazywali także - oprócz znaczenia twórczości dla samej osoby - na jej otwartość względem drugiego człowieka. Analizę tej kategorii wypowiedzi przedstawiono w kolejnej części artykułu.

\section{3) Twórczość jako powinność wobec innych}

W swoich wypowiedziach nauczyciele podkreślali, że twórczość ma także znaczenie społeczne. Jeden z nich stwierdził: „Twórczość stanowi podstawę rozwoju osobistego i zawodowego uczniów i nauczycieli o kierunkach ścisłych. Nieszablonowe podejście, nowe pomysły rozwiązania już rozwiązanego zadania. Przez swoją twórczość osoba staje się o wiele bardziej atrakcyjna dla rynku pracy. Wiele firm nie poszukuje osób o określonych umiejętnościach, ale o cechach takich, jak kreatywność czy twórczość. Zarówno od uczniów z wysokimi kompetencjami w zakresie przedmiotów ścisłych oczekuje się twórczego, kreatywnego podejścia. Takie podejście pozwala na nowe odkrycia, nowe rozwiązania. Podsumowując, moim zdaniem twórczość powinna być przedmiotem rozwoju osobistego każdego z uczniów, ale także i nauczycieli, którzy stanowią wzór osoby dla ucznia".

Twórczość, a raczej wysoki poziom zdolności twórczych, jest właściwością bardzo pożądaną z punktu widzenia działalności zawodowej, bez wzglę$\mathrm{du}$ na dyscyplinę. Racjonalny pracodawca będzie postrzegał twórczość swoich pracowników jako gwarancję rozwoju własnej działalności, a także 
jako zabezpieczenie na wypadek wystąpienia trudności lub zmiany. W tym kontekście twórczość może być postrzegana jako narzędzie rozwoju gospodarczego, ekonomicznego, społecznego itp.

Jednak ten pragmatyczny aspekt twórczości, mimo iż zazwyczaj przedstawiany jako podstawowy, jest jedynie konsekwencją innych jej właściwości. Jeden z nauczycieli zaznacza: „Każda osoba ze swojej istoty i bogactwa osobowości jest twórcza. Twórczością jest zarówno życie osobiste człowieka, jak i jego praca, zaangażowanie w dobro, w pomoc innym, w czynienie tego świata lepszym. Twórczość otwiera nowe horyzonty, jest wyzwaniem i zadaniem zarówno w stosunku do siebie, jak i otaczającego świata, osób, relacji”.

Głównym celem twórczości staje się urzeczywistnianie dobra dla osoby. Nie tylko dla siebie samego, ale również dla drugiego człowieka. Przekształcanie rzeczywistości, rozwój cywilizacji, które są efektem działań twórczych, dokonują się dla człowieka, aby jego egzystencja w świecie była realizacją dobra, prawdy i piękna. Inny badany uznał także, że „Twórczość to potrzeba. Człowieka potrzebujemy konstruować, odkrywać, poznawać nowe, wyzwalać swoją kreatywność. Tworzymy dla siebie i dla innych, to daje nam satysfakcję, radość i rozwija".

Podejmowanie aktywności twórczej dla dobra drugiego człowieka umożliwia wzrastanie osoby tworzącej w jej człowieczeństwie. Staje się czynnikiem wspomagającym transcendencję osoby. Twórczość ukierunkowana na drugiego człowieka jest przestrzenią, w której osoba przezwycięża własne ograniczenia.

Należy także pokreślić, iż efekty działalności twórczej stanowią świadectwo życia dla kolejnych pokoleń. Jeden z nauczycieli zauważa: „Twórczość to umiejętność kreowania świata w kreatywny i ciekawy dla odbiorcy sposób za pomocą różnych środków oraz narzędzi. Jest to zadanie każdego nauczyciela, ale też każdego rodzica i osoby w ogóle po to, aby zostawić po sobie jakąś spuściznę".

Z wykorzystania możliwości tworzenia oraz z efektów samej twórczości społeczeństwa teraźniejszości będą „rozliczane” przez społeczeństwa przyszłości. Na fundamencie kolejnych wytworów jest budowana przyszłość każdej osoby oraz całych cywilizacji. Kształt przyszłej rzeczywistości zależy od tego, w jakich kierunkach i w jakim stopniu w sposób zrównoważony będzie urzeczywistniana działalność twórcza.

W tym kontekście zasadne staje się wskazanie, iż twórczość stanowi szczególnie istotne zadanie dla nauczycieli - tę konieczność podkreślali także badani. 


\section{4) Twórczość jako zadanie nauczyciela}

Nauczyciele, zwracając uwagę na społeczny aspekt twórczości, podkreślali, że działalność twórcza staje się szczególnym zadaniem dla tej grupy zawodowej. Jeden z nauczycieli wskazuje: „Nauczyciel jest współtwórcą przyszłości swoich uczniów. Tworzy w każdym z nich zalążek, który w przyszłości będzie kiełkował podczas wyboru ścieżki życiowej”.

Wychowawca przygotowuje ucznia do pełnienia funkcji aktywnego twórcy. Stanowi dla niego inspirację, jest jego przewodnikiem i wiernym towarzyszem. W procesie towarzyszenia nauczyciel pozostawia wychowankowi wolność tworzenia, a także zapewnia przestrzeń do realizowania aktywności twórczej. Jeden z badanych stwierdza: „Twórczość kojarzy mi się z kreatywną nauką, tworzeniem czegoś nowego, pomysłowego, ciekawego, zachęcającego. Jako wychowawca przedszkolny codziennie poprzez swoją pracę, będąc twórczym/kreatywnym, uczę dzieci, jak być właśnie taką osobą. Zadaniem nauczyciela jest potraktowanie każdego dziecka indywidualne, zaznajomienie się z jego umiejętnościami, zdolnościami. Wychowawca kieruje potencjałem dziecka. Może pokazać mu i rozwijać to, w jakiej dziedzinie radzi sobie najlepiej (plastyka, języki obce, sport). Twórczość jest zatem zadaniem nauczyciela. Nauczyciel mało twórczy nie zachęca dzieci do nauki. Bycie twórczym to ogromny dar, który należy pielęgnować”.

Aby rozpoznać potencjał twórczy wychowanka, nauczyciel musi zdynamizować własną aktywność twórczą i ukierunkować ją na realizację procesu wychowawczo-dydaktycznego. Autentyczne zaangażowanie w te działania zaowocuje także rozbudzeniem fascynacji, twórczością u uczniów. Jeden z badanych nauczycieli podkreśla: „Przede wszystkim zastanówmy się, czym jest twórczość. W pierwszej chwili kojarzy się z artystycznym tworzeniem. Po chwili jednak odczuwam, że twórcami są wynalazcy, budowniczowie. Nie zapominam jednak i tych, którzy pomagają lepić młode dusze. Najpierw są to rodzice, którzy nawet jeśli myślą, że mają przed sobą pustą tablicę, to mają obowiązek pomóc tworzyć pewność siebie w swoich dzieciach, aby te mogły następnie tworzyć świat na podstawie swoich umiejętności. Następnie dzieci idą do placówek, gdzie zderzają się przede wszystkim z nową społecznością. W ten sposób dobrze, aby znaleźli innych niż ich rodzice dorosłych, dzięki którym odkryją swoje mocne strony, dzięki którym będą mogli mieć wpływ na świat. Tymi osobami są nauczyciele - oni z jednej strony mogą pomóc rozwinąć skrzydła, lecz bardzo często raczej je niestety wyrywają". 
Zawód nauczyciela „domaga” się i potrzebuje twórczości. Włączona w proces wychowawczo-dydaktyczny, twórczość rozwija zarówno wychowawcę, jak i wychowanka.

Podsumowując powyższe analizy należy zaznaczyć, iż twórczość jest zadaniem osoby - jest jej powinnością wobec społeczności. W tym zakresie:

- twórczość jest urzeczywistnieniem dobra dla drugiego człowieka;

- twórczość stanowi narzędzie rozwoju gospodarczego, ekonomicznego, społecznego itp.;

- nauczanie jest twórczością i procesem przygotowującym do twórczości.

W niniejszym artykule podjęto analizy nad twórczością, która jest rozpatrywana jako zadanie osoby. Poszukiwano odpowiedzi na problem zawierający się w pytaniu: W czym wyraża się twórczość jako zadanie osoby? $\mathrm{Na}$ podstawie literatury oraz swobodnych wypowiedzi nauczycieli została sformułowana następująca odpowiedź na tak postawiony problem: twórczość jako zadanie osoby wyraża się w dwóch kontekstach:

1. Kontekst wskazujący na ontyczność twórczości wobec bytu osoby, wyrażającą się:

- we wzajemnej relacji trwania twórczości i osoby;

- w przynależności twórczości każdemu człowiekowi, przy jednoczesnym wyznaczaniu jego wyjątkowości i indywidualności;

- w integralnym powiązaniu wielowymiarowości twórczości oraz wielowymiarowości człowieka;

- w odkrywaniu własnego ja.

2. Kontekst wskazujący na teleologiczny wymiar twórczości dla osoby, wyrażający się jako:

- powołanie osoby;

- czynnik rozwoju osoby;

- powinność osoby wobec społeczności.

BIBLIOGRAFIA

ChaŁas, K., Łobacz, M. (2020). Przymioty osoby ludzkiej: edukacja aksjologiczna i wychowanie ku wartościom. Lublin: Wydawnictwo KUL.

KACZMARSKA, B. (2017). Twórczość artystyczna z życiu osób z niepełnosprawnością - indywidualny i społeczny wymiar arteterapii. Niepetnosprawność - zagadnienia, problemy, rozwiązania, 1(22), 107-129. 
KozIELECKI, J. (1996). Człowiek wielowymiarowy. Wyd. 2 poprawione. Warszawa: Wydawnictwo Akademickie „Żak”.

Mendecka, G. (2005). Twórczość a rozwój człowieka w biegu życia. Psychologia Rozwojowa, 10(4), 23-34.

NAJder-Stefaniak, K. (2016). Twórczość. W: K. Chalas, A. Maj (red.), Encyklopedia aksjologii pedagogicznej (s. 1183-1188). Radom: Polskie Wydawnictwo Encyklopedyczne Polwen.

NALASKOWSKI, A. (1998). Społeczne uwarunkowania twórczego rozwoju jednostki. Warszawa: Wydawnictwa Szkolne i Pedagogiczne.

NęCKA, E. (2016). Psychologia twórczości. Gdańsk: Gdańskie Wydawnictwo Psychologiczne.

SzMIDT, J. K. (2009). Współczesne podejścia w pedagogicznych badaniach nad twórczością: przegląd wybranych stanowisk. W: K. J. SzMIDT (red.), Metody pedagogicznych badań nad twórczością. Łódź: Wydawnictwo AHE.

SzMidT, K. J. (2013). Pedagogika pozytywna: twórczość - zdolności - mądrość zespolone. W: K. J. Szmidt, M. ModrzeJewskA-ŚWigulska (red.), Zasoby twórcze człowieka. Wprowadzenie do pedagogiki pozytywnej (13-40). Łódź: Wydawnictwo UŁ.

SZYMAŃSKA, M., SZYMAŃSKI, S. (2017). Twórcza postawa człowieka wobec realizacji jego życiowego powołania. W: A. WALUlik, J. MóŁKA (red.), Septuaginta pedagogiczno-katechetyczna (225-237). Kraków: Wydawnictwo Ignatianum.

\section{TWÓRCZOŚĆ JAKO ZADANIE OSOBY}

\section{STRESZCZENIE}

Niniejszy artykuł przedstawia refleksję nad twórczością, rozumianą jako zadanie osoby. Główny problem badawczy zawiera się w pytaniu: w czym wyraża się twórczość jako zadanie osoby? W pierwszej części artykułu został zaprezentowany przegląd perspektyw rozumienia twórczości, które są przedstawione w literaturze. W części drugiej przeprowadzono analizę jakościową swobodnych wypowiedzi nauczycieli. Podjęte analizy umożliwiły sformułowanie odpowiedzi na postawiony problem badawczy.

Słowa kluczowe: twórczość; osoba; zadanie osoby.

\section{CREATIVITY AS A TASK OF A PERSON}

SUMMARY

The article below presents a reflection on creativity, understood as a person's task. The main research problem is contained in the question: what is creativity expressed as a task of a person. The first part of the article reviews the perspectives of understanding creativity that are presented in the literature. In the second part, a qualitative analysis of teachers' free speech was carried out. The undertaken analyzes made it possible to formulate a response to the research problem posed.

Keywords: creativity; person; person's task. 